\title{
Kazukuru gen. nov. - a new Ricaniidae planthopper from Solomon Islands (Hemiptera, Fulgoromorpha)
}

\author{
Adam Stroiński ${ }^{1}$ \\ 1 Museum and Institute of Zoology, Polish Academy of Sciences, Wilcza 64, 00-679 Warszawa, Poland \\ http://zoobank.org/0582A044-ECD6-4565-823E-3E6E06DBC6F5 \\ Corresponding author: Adam Stroiński (adam@miiz.waw.pl)
}

Academic editor: Michael Wilson • Received 26 January 2021 • Accepted 10 March 2021 • Published 31 March 2021

\begin{abstract}
A new monotypic genus of ricaniid planthoppers (Hemiptera: Fulgoromorpha: Ricaniidae) from New Georgia Island (Solomon Islands), Kazukuru gen. nov., is described for K. zingiberis sp. nov. (type species). Habitus, female, external and internal genital structures of the new species are described and illustrated.
\end{abstract}

\section{Key Words}

Fulgoroidea, Oceanian Region, New Georgia, taxonomy, morphology, eggs

\section{Introduction}

The planthopper family Ricaniidae Amyot et Audinet-Serville, 1843 consists of 67 genera $(2.7 \%$ of the Fulgoromorpha) and covers 437 species $(3.2 \%$ of the Fulgoromorpha) (Bourgoin 2021).

The fauna of Ricaniidae of the Solomon Islands is not very rich. Only six genera with thirteen species and one subspecies have been recorded from the Solomon Islands. These are: Armacia hyalinata (Donovan, 1805) - Guadalcanal Is., Vella Lavella Is., A. atrofascialis Distant 1911 - Solomon Islands; Euricania discigutta (Walker, 1862) - Solomon Islands, E. gloriosa Distant, 1911 - Solomon Islands; Parapiromis guadalcanalensis Bu, Larivière \& Liang, 2010 - Guadalcanal Is., Malaita Is., P. santacruzensis Bu, Larivière \& Liang, 2010 - Santa Cruz Is., P. hieron (Fennah, 1970) - Rennell Is.; Ricania corusca Van Duzee, 1940 - Santa Catalina Is., R. lutescens Distant, 1911 - Solomon Islands, $R$. sigillata Van Duzee, 1940 - Malaita Is.; Ricanula conspersa (Melichar, 1898) - Shortland Is., R. trimaculata trimaculata (Guérin-Méneville, 1838) - Shortland Is., R. trimaculata rennelli Fennah, 1970 - Rennell Island; Tarundia curtula Melichar, 1898 - Shortland Is.

Unfortunately, the exact location is known only for some species, with others (four species) recorded only generally. All of these species belong to widely distributed genera.
The new genus described below, based on two females, is unique in family Ricaniidae and known only from a single locality.

\section{Material and methods}

Dry pinned specimens were used for this study.

Label information for all specimens examined is provided verbatim with each line separated by a slash (/) and each label given in square brackets.

\section{Terminology}

The nomenclature of fore wing (tegmen) follows the interpretation proposed by Bourgoin et al. (2015) and Stroiński (2020). Antennal structures are named in accordance with Stroiński et al. (2011). The terminology of the genitalia follows Bourgoin (1988) and Bourgoin and Huang (1990) for the male and Bourgoin (1993) for the female. The whole abdomen of the specimen examined was cut off and cleared for $30 \mathrm{~min}$ in a warm $\left(50{ }^{\circ} \mathrm{C}\right) 10 \%$ potassium hydroxide $(\mathrm{KOH})$ solution with a few drops of black chlorazol (CAS No. 1937-37-7) for staining the ectodermic genital structures, based on the method introduced by Carayon 
(1969). Dissections and cleaning of the genital structures were carried out in distilled water. Final observations were made in glycerol using an Olympus SZH10 stereomicroscope. The photographs of the habitus and internal structures were taken using a stereomicroscope Leica MZ 16 with IC3D camera. Final images were adjusted using Helicon 5.0 software and Adobe Photoshop (version 7.0).

The SEM photographs of uncoated specimens were taken in the Laboratory of Scanning Microscopy, MIZ PAS (Warsaw), using a scanning electron microscope HITACHI S-3400N under low vacuum conditions.

\section{Measurements and abbreviations.}

Measurements were made with an ocular micrometer. The following measurements, ratios and their abbreviations were used in this study:

Total length measured (in dorsal view) from head apex to tegmina apex;

A/B width of vertex measured at anterior margin / length of vertex measured at mid-line;

$\mathbf{C} / \mathbf{E} \quad$ width of frons at upper margin / length of frons at mid-line;

$\mathbf{D} / \mathbf{E} \quad$ maximum width of frons / length of frons at mid-line;

F/B length of pronotum at mid-line / length of vertex at mid-line;

G/F length of mesonotum / length of pronotum at mid-line;

$\mathbf{G} / \mathbf{B}+\mathbf{F}$ length of mesonotum / cumulative length of vertex and pronotum at mid-line;

G/H length of mesonotum at mid-line / width of mesonotum between lateral angles;

$\mathbf{I} / \mathbf{J}$ length of tegmen measured from the base to the apical margin in median portion / width of tegmen measured at the widest part.

The material studied is deposited in Bernice P. Bishop Museum, Honolulu, Hawaii, USA (BPBM).

\section{Results}

Class Insecta Linnaeus, 1758

Order Hemiptera Linnaeus, 1758

Suborder Fulgoromorpha Evans, 1946

Superfamily Fulgoroidea Latreille, 1810

Family Ricaniidae Amyot \& Audinet-Serville, 1843

Subfamily Ricaniinae Amyot \& Audinet-Serville, 1843

\section{Genus Kazukuru gen. nov.}

http://zoobank.org/FC2D5242-4CC3-4DFF-B747-E4C8303E84D5

(Figs 1-60)

Type species. Kazukuru zingiberis sp. nov., by present designation and monotypy.
Etymology. The generic name Kazukuru refers to an extinct language once spoken in New Georgia (Solomon Islands). Kazukuru language was last recorded in the early twentieth century when its speakers were in the last stages of language shift (Dunn and Ross 2007). Gender neuter.

Diagnosis. The genus Kazukuru gen. nov. can be distinguished from all other genera in Ricaniidae by the following combination of characters: frons with three carinae separated at base (Figs 12 and 13), frontal disc with transverse massive thick shaft; all longitudinal veins leaving basal cell separately (Fig. 20); tegmen's cells C1 and C5 open; basimetatarsomere with two rows of partly flattened teeth (Fig. 30); all teeth of similar size; posterior margin of gonoplac with two rows of teeth: first row with well-developed teeth (Fig. 42) - larger interspersed with smaller ones, second row with very small, weaklydeveloped teeth placed irregularly.

Description. Head. Head with compound eyes (in dorsal view) narrower than thorax.

Vertex (Figs 2-3 and 11-13) transverse, with all margins well carinated, distinctly wider at level of anterior margin angles than long at mid-line, posterior angles placed about level of mid-length of compound eyes; posterior margin slightly elevated. Disc of vertex without median carina.

Frons (Figs 2-5 and 11-15) transverse, with all margins well carinated; frons at upper margin slightly wider than high at mid-line, widest near level of lower part of compound eyes and distinctly wider than high at mid-line; lateral margins distinctly bent before half of frons, covering base of pedicel, not incised at level of ocelli. Upper part of frons to level of transverse eminence protruded, below eminence retracted; disc of frons smooth.

Frontal disc tricarinate, all carinae (median and lateral) separated at upper margin of frons and all carinae reaching ventrad to transverse bar before frons mid-length (not extending the 'breaking' point of lateral margins); median carina straight, ending in thick transverse shaft; lateral carinae parallel to lateral margins, subparallel to each other, just longer than median carina and slightly extending transverse thick shaft; transverse thick shaft massive; surface of frontal disc smooth. Frontoclypeal suture straight.

Clypeus (Figs 2-4 and 12-13) triangular, narrowed ventrally; distinctly narrower than frons, without carinae.

Rostrum (Figs 2-4 and 14, 17), with apical segment shorter than subapical one, reaching mid-coxae.

Compound eyes (Figs 6 and 8) rounded with an extremely narrow callus at posterior margin. Ocelli present, large, located near ventro-anterior edge of eye, above antenna.

Antenna (Figs 13, 18-19 and 25-26): scape short, wider than long; pedicel more elongate with slightly wider tip, with functional area (trichoid sensilla type 1 and antennal plate organs) present on top and tip of dorsal surface and distinctly smaller area on ventral surface; plate organs of crenellated type surrounded by a ring of elevated spines. 
1

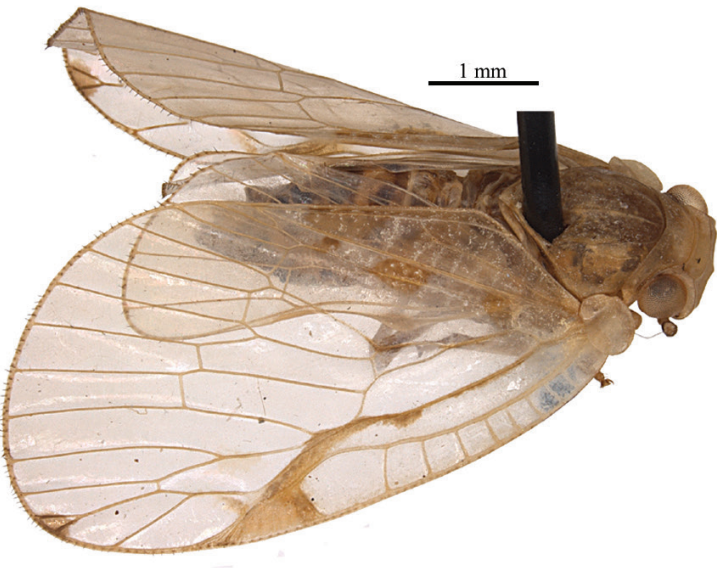

2
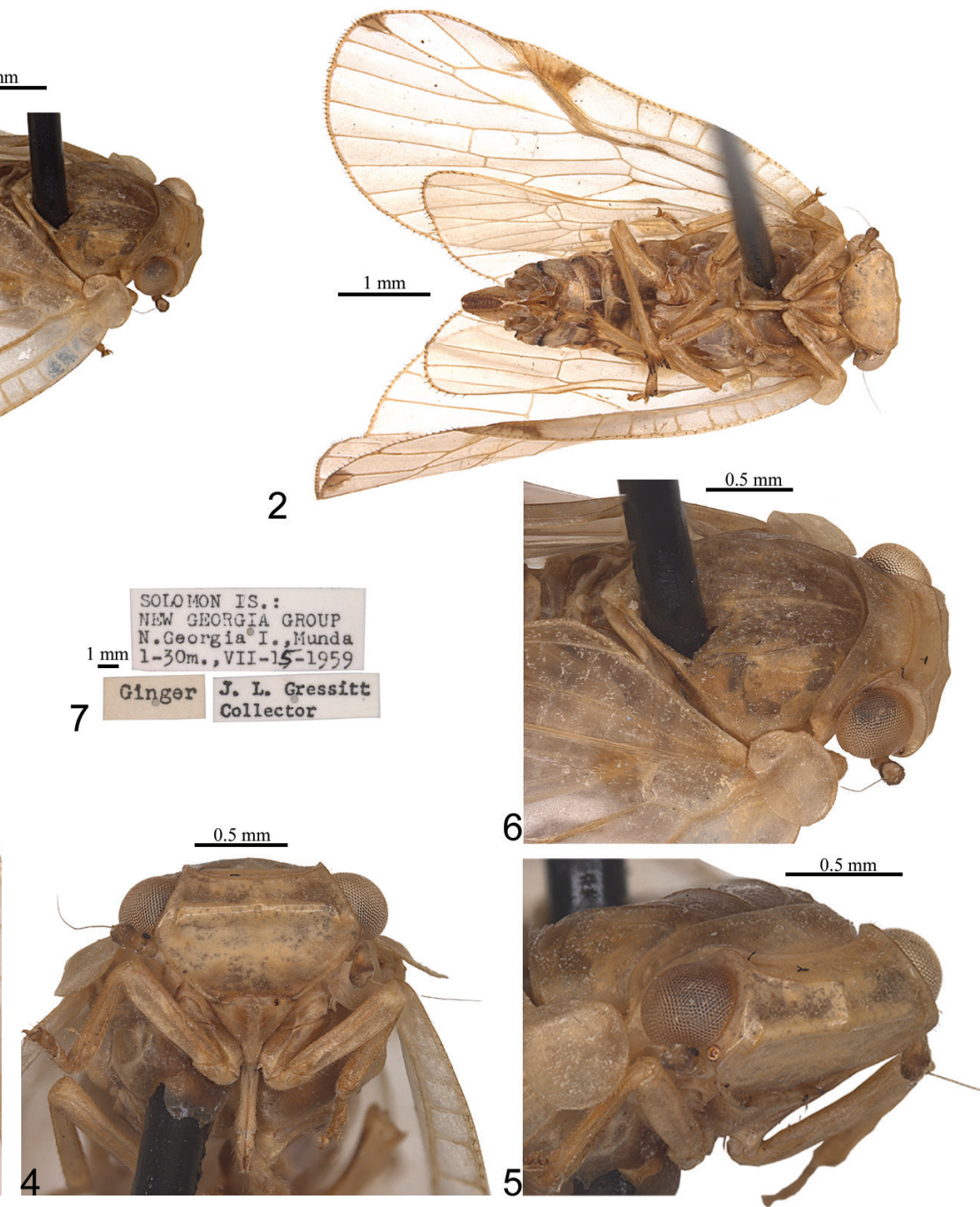

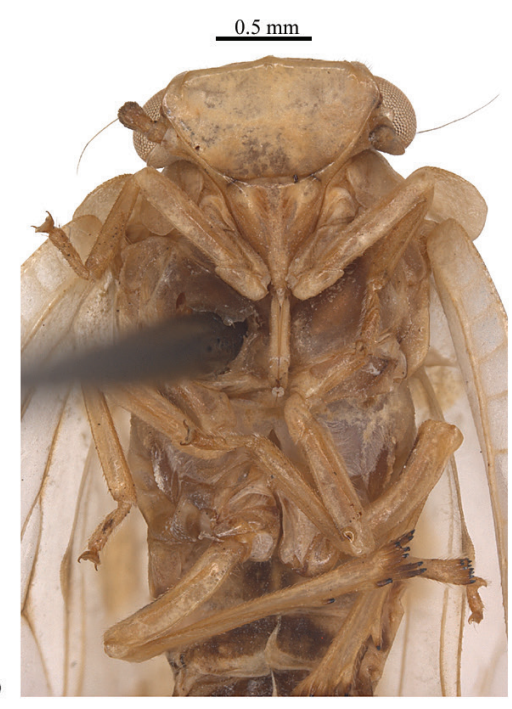

Figures 1-7. Kazukuru zingiberis gen. et sp. nov; 1. Habitus, dorso-lateral view; 2. Same - ventral view; 3. Head and thorax, ventral view; 4. Head and rostrum ventral view; 5. Head and thorax, fronto-dorsal view; 6. Same, dorso-lateral view; 7. Labels.

Thorax. Pronotum (Figs 1, 6 and 8-11) distinctly wider than vertex at mid-line; disc of pronotum with median carina and two lateral impressions; anterior part medially produced medially truncate; posterior margin weakly concave; pronotum ascending posteriorly.

Mesonotum (Figs 1, 6 and 8-11) about as long in mid-length as wide in lateral angles, distinctly longer at mid-line than combined length of vertex and pronotum; median, lateral and anterolateral carinae present; median carina and lateral carinae connected anteriorly in one point; median carina reaching scutellum, lateral carinae reaching posterior margin; anterolateral carinae connected with lateral carinae after lateral angles of mesonotum; lateral angles placed before mid-length of mesonotum.

Tegmina (Figs 1-2 and 20-24) membranous with small sclerotised area in distal part of costal area and postcostal cell, elongately rounded, flattened, with distinct longitudinal venation with incomplete apical line of transverse veinlets.

Costal margin weakly arcuate, apical angle broadly rounded distad to claval angle; claval angle widely rounded; posterior margin arcuate with; postclaval margin (tornus) absent.

Costal area with dense transverse veinlets ending slightly after level of tip of clavus, in basal half about as wide as postcostal cell; subapically expanded and tapering distad.

Postcostal cell in proximal half as wide as costal area in posterior part distinctly narrower without transverse veinlets. Basal cell large, elongately rounded, about 1.5 times longer than wide.

Longitudinal veins $\mathrm{ScP}+\mathrm{R}, \mathrm{MP}$ and $\mathrm{CuA}$ leaving basal cell separately; veins $\mathrm{ScP}+\mathrm{RA}$ and $\mathrm{RP}$ arising as long common stem from basal cell with first fork distad of MP and $\mathrm{CuA}$ forks and about level with tip of clavus; cell $\mathrm{C} 1$ open; first fork of MP before half of tegmen, branch $\mathrm{MP}_{1}$ touching/fused with vein $\mathrm{ScP}+\mathrm{R}$. CuA with dichotomic model of forking, first fork placed between first forks $\mathrm{ScP}+\mathrm{R}$ and MP, before tip of costal area and before tip of clavus.

Tegmina with single apical line of transverse veinlets; apical cell distinctly longer than wide, median cell large, approximately trapezoidal. 

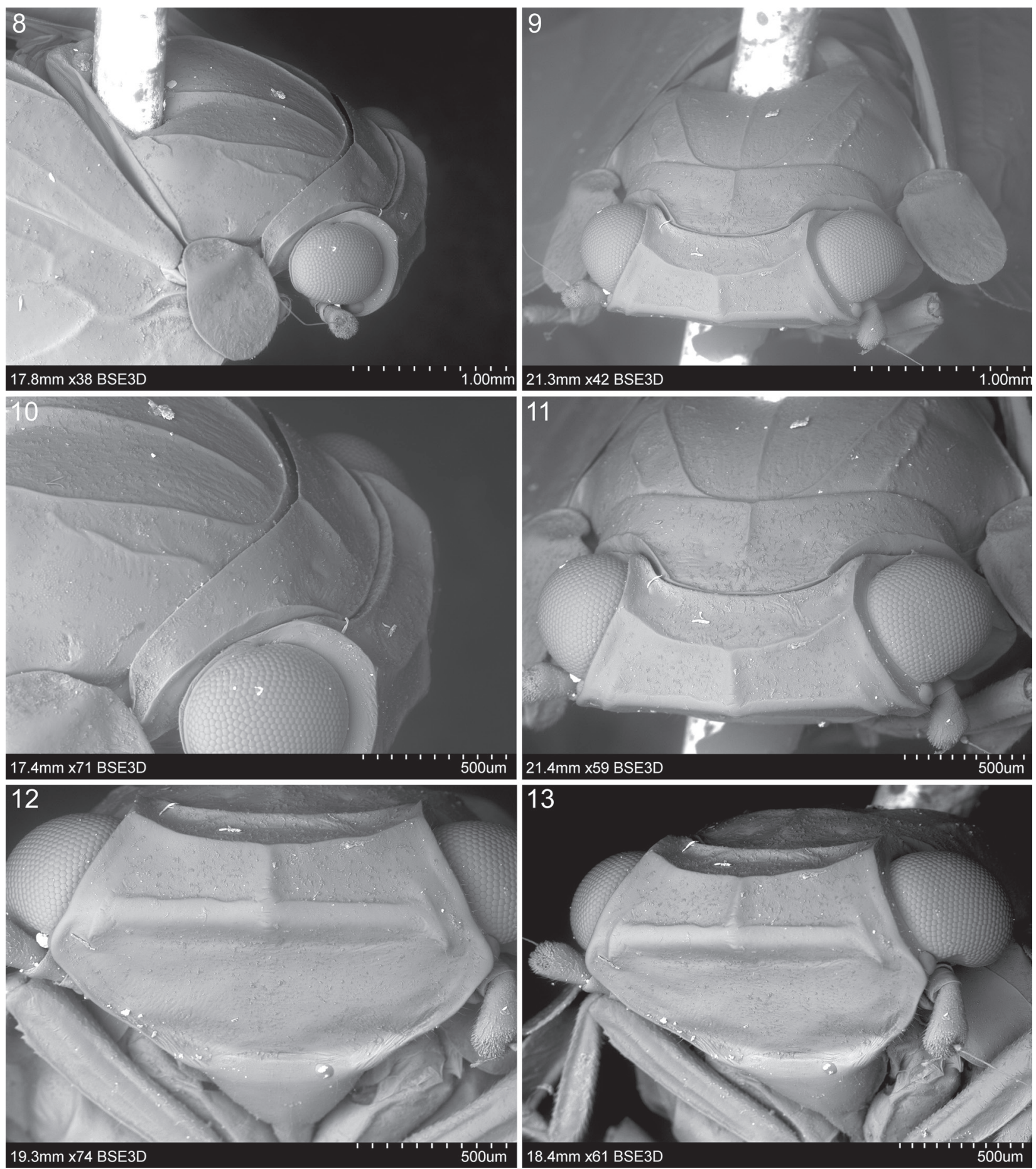

Figures 8-13. Kazukuru zingiberis gen. et sp. nov., SEM micrographs; 8. Head and thorax, latero-dorsal view; 9. Same, fronto-dorsal view; 10. Anterior part of body latero-dorsal view; 11. Same, fronto-dorsal view; 12. Frons and clypeus, frontal view; 13. Head frontal view.

Cubital cell without transverse veinlets. Clavus closed; claval veins Pcu and $\mathrm{A}_{1}$ fused just after mid-length of $\mathrm{CuP}$ vein; posterocubital cell at basal part and posterior part with scarce transverse veinlets; postcubital and anal cell without transverse veinlets.

Hind wings with precostal triangular cell present; $\mathrm{ScP}+\mathrm{R}$ distinctly after mid-length of wing, MP not forking, single; $\mathrm{CuA}$ forking about middle of wing distantly before first of $\mathrm{ScP}+\mathrm{R}$ before $\mathrm{ScP}+\mathrm{R}$ and MP fork, slightly after half of wing; two transverse veinlets present in distal part of wing: $r p$-mp, $m p$-cua.

Protibia and profemur about same length; mesofemur slightly shorter than mesotibia; ventral margin of profemur apically with few small variable teeth (Figs 2-3 and 14).

Hind legs (Figs 3 and 27-30): metatibia distinctly longer than metafemur, partly flattened and widened at distal part; metatibia with two lateral spines on dis- 

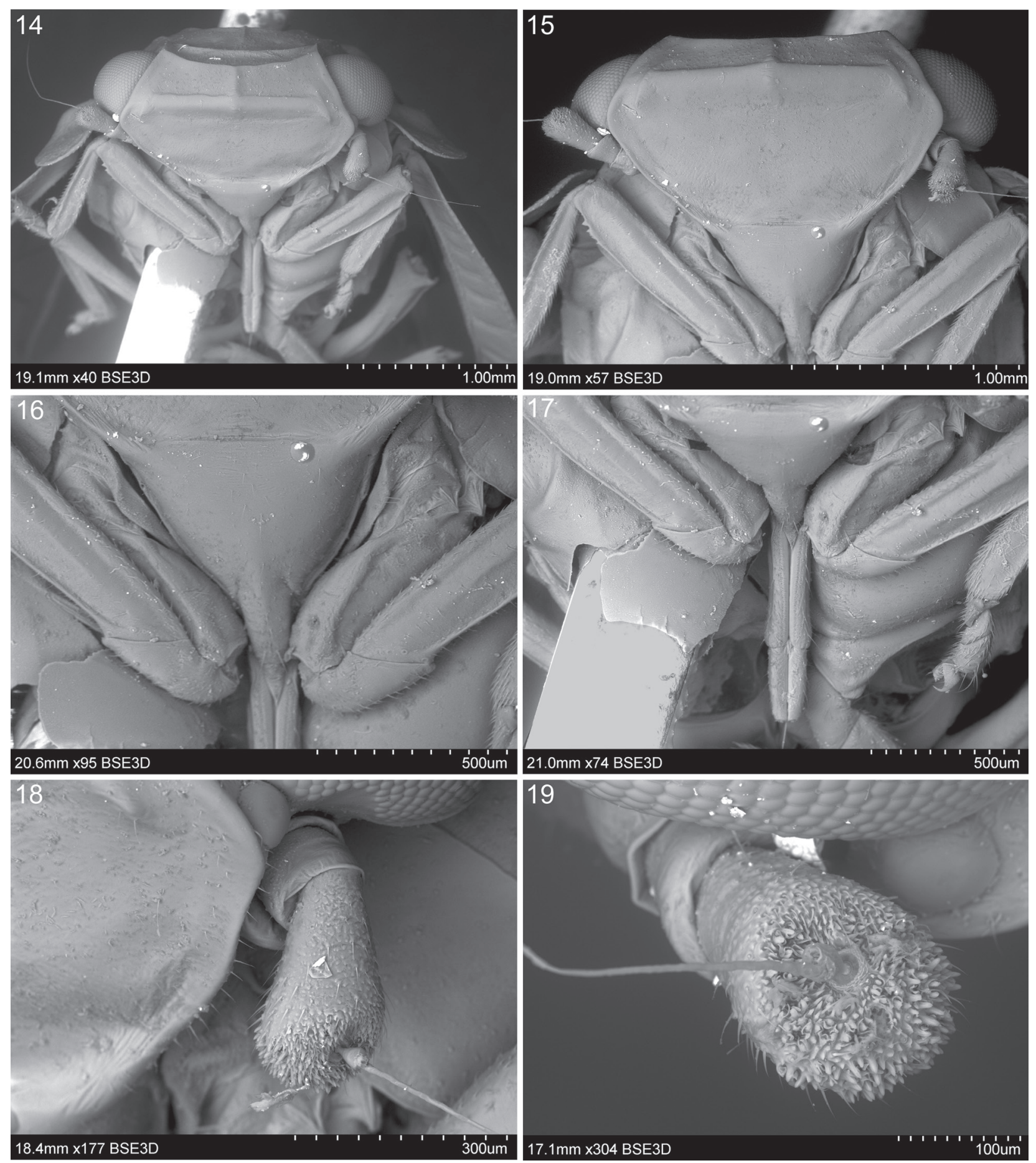

Figures 14-19. Kazukuru zingiberis gen. et sp. nov., SEM micrographs; 14. Head, rostrum and legs, frontal view; 15. Same, higher magnification; 16. Clypeus, frontal view; 17. Rostrum, ventral view; 18. Antenna, fronto-lateral view; 19. Top of antenna, frontal view.

tal half; apical row of teeth huge, irregular, with seven $(2+5)$ well-developed spines, different in size and without diastema; lateral spines similar in size; five internal teeth of differing size, lateral like external teeth, three internal ones distinctly smaller then lateral with median tooth longer.

Basimetatarsomere longer than cumulative length of second and apical metatarsomeres, with two linear rows of partly flattened teeth; all teeth similar size, apical line with seven teeth, second row narrower, with three teeth; all teeth without setae on ventral side of teeth.

\section{Male. Unknown.}

Female terminalia (Figs 31-36 and 49-60). Pregenital sternite massive (Figs 46-48, 54 and 58) with well developed, elongately-rounded and distinctly separated lateral lobes; median part of pregenital sternite wide, anterior margin medially weakly concave, posterior margin medially. Anal tube (in lateral view, Figs 55-56) elon- 

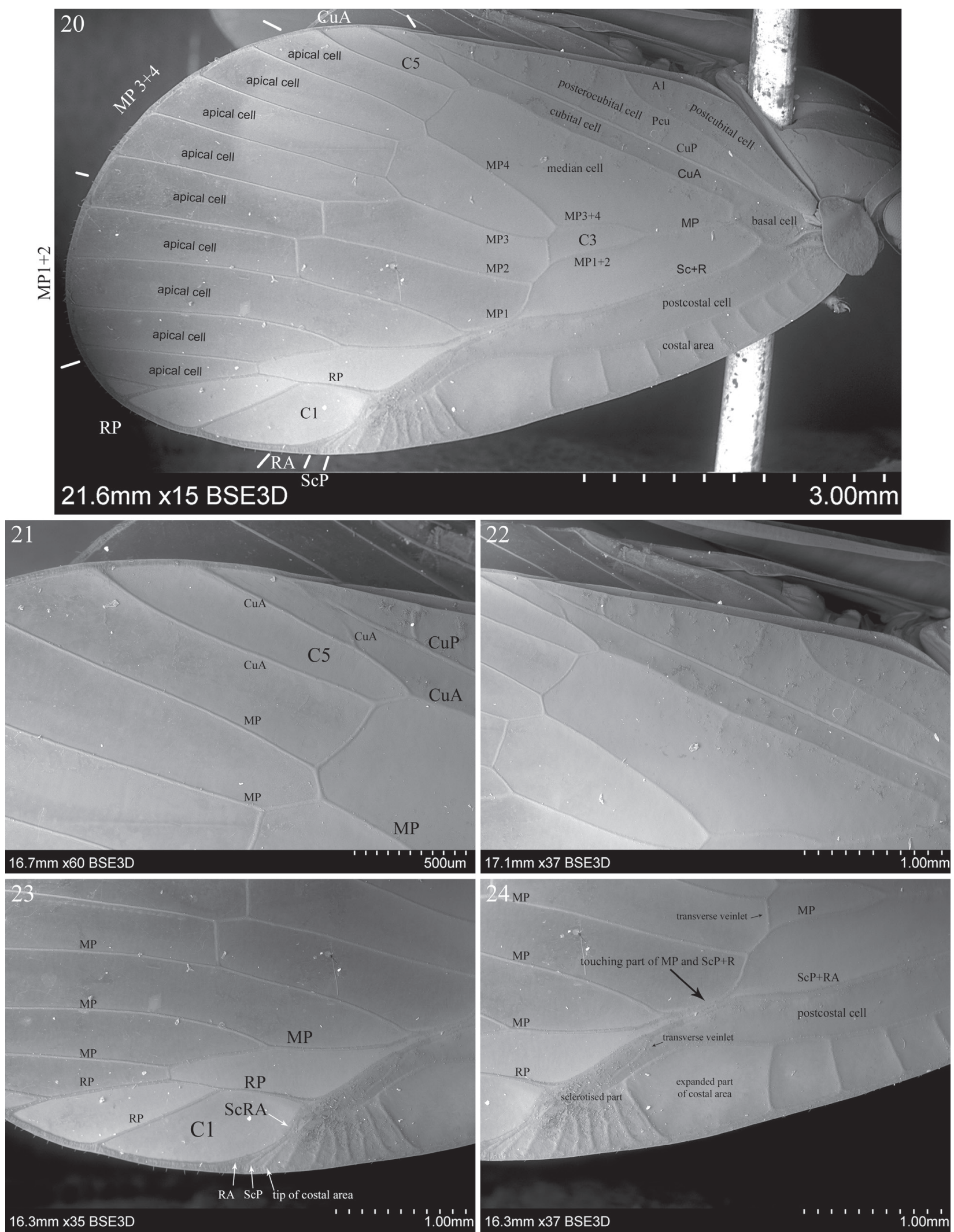

Figures 20-24. Kazukuru zingiberis gen. et sp. nov., SEM micrographs; 20. Tegmen, lateral view; 21. Claval angle area, lateral view; 22. Clavus, lateral view; 23. Costal angle area, lateral view; 24. Tip of costal area and postcostal cell, lateral view.

gate, extending half of upper margin of gonoplac, but not reaching posterior margin; basal part of anal tube distinctly wider than posterior one; anal opening, in dorsal and lateral view, placed after mid-length; anal tube (in dor- sal view, Figs 50 and 55) elongately club-like, distinctly wider after mid-length; anal style (paraproct) short not extending posterior margin of anal tube and anal segment (epiproct) long extending posterior margin. 

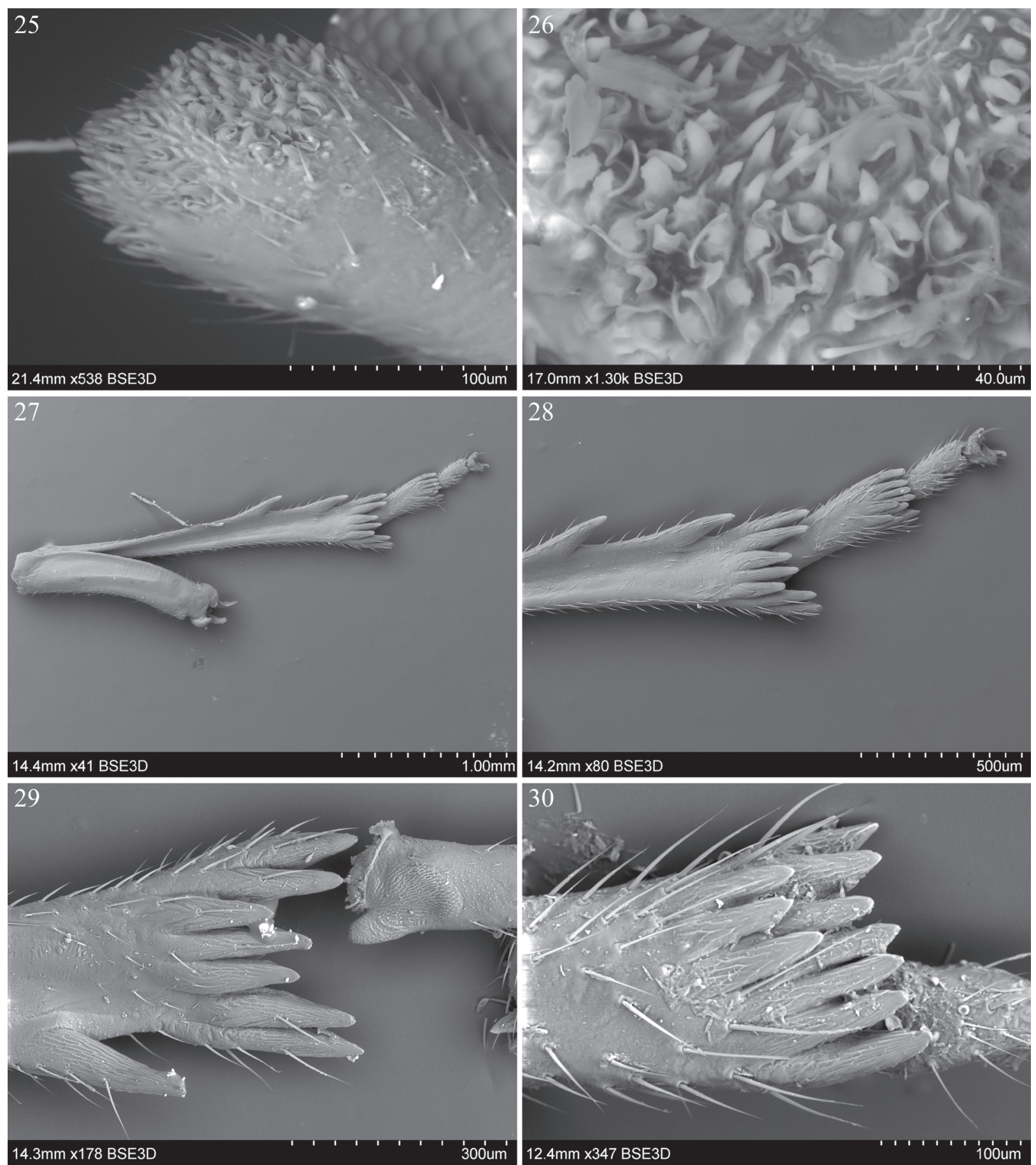

Figures 25-30. Kazukuru zingiberis gen. et sp. nov., SEM micrographs; 25. Apex of antenna, lateral view; 26. Plate organs; 27. Hind leg, ventral view; 28. Distal part of tibia and tarsus, ventral view; 29. Apical part of hind tibia; 30. Apical part of basimetatarsomere.

Gonoplac (Figs 41-43, 46, 49-52, 55 and 59) well developed, unilobate, laterally flattened; posterior margin of gonoplac with double rows teeth for nearly full length of posterior margin; first row teeth well-developed - larger interspersed with smaller, second row small, weakly developed and irregularly placed; membranous parts of gonoplac present: first narrow weakly sclerotised placed on lower part of posterior margin below teeth, second one large fully membranous, placed ventro-basad part of gonoplac.

Gonapophysis VIII (Fig. 57) elongate, sabre-like, "v"-shape in cross section, with teeth at posterior part of dorsal margin; endogonocoxal process membranous, tapering apicad with very narrow tip, a bit shorter than gonapophysis VIII, without sclerotised belt.

Gonaphophyses IX and gonospiculum bridge well developed (as in Figs 58-59).

Bursa copulatrix of two pouches connected with short ductus; first pouch elongate, with cells and sclerotised ornamentation (except dorsal part) with sclerotised plate with 5-8 small petals, but without median huge sclerite; second pouch elongate-oval, smaller than first one, without cells and without sclerotised plates. 

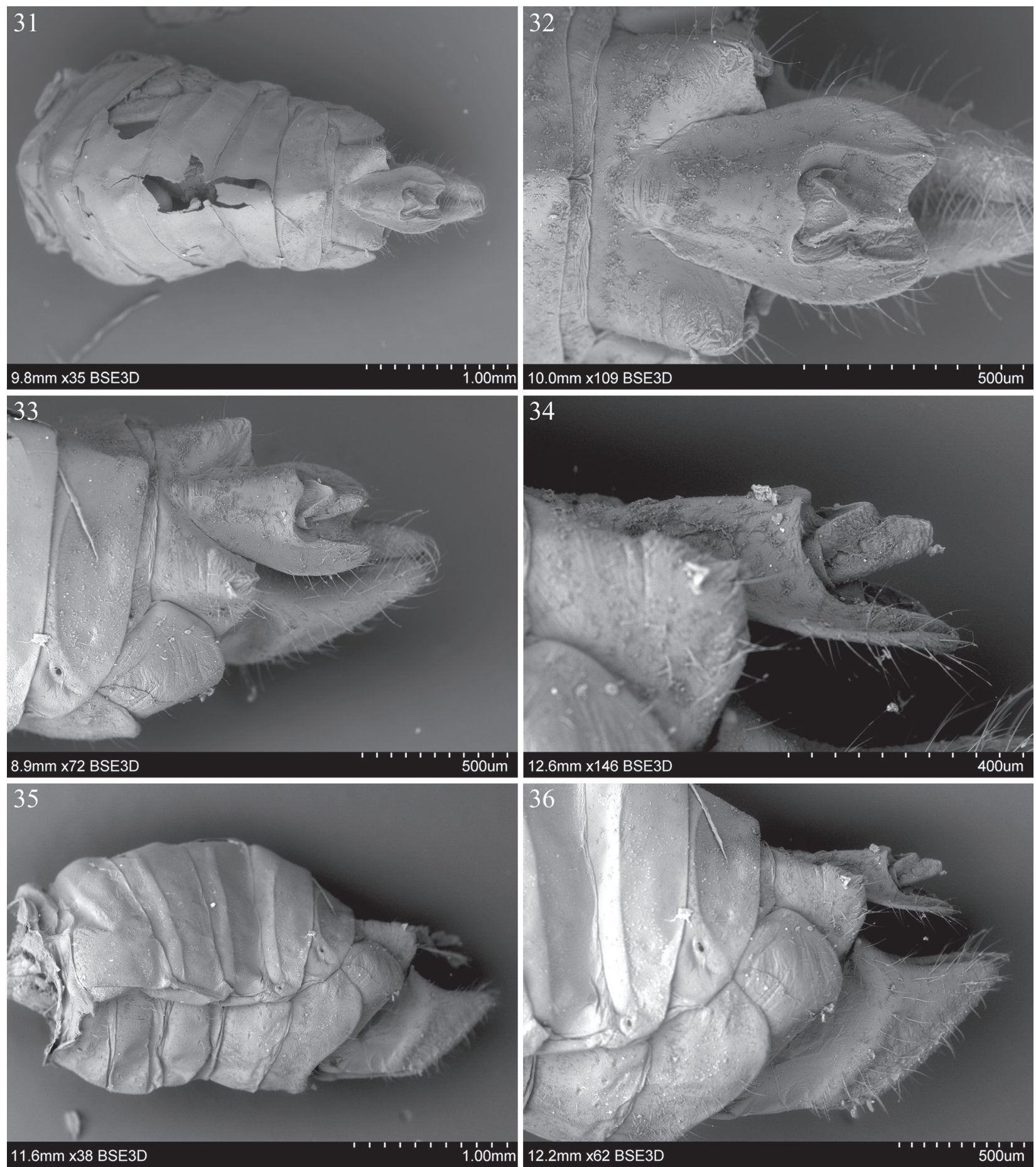

Figures 31-36. Kazukuru zingiberis gen. et sp. nov., SEM micrographs, female terminalia; 31. Abdomen and terminalia, dorsal view; 32. Anal tube, dorsal view; 33. Same, dorso-lateral view; 34. Same, lateral view; 35. Abdomen and terminalia, lateral view; 36. Terminalia, lateral view.

Spermatheca (Fig. 60) well developed; ductus receptaculi elongate, smooth and narrow; diverticulum ductus with two parts (basal shorter then apical), distinctly longer than ductus receptaculi, with long wide smooth ductus and long smooth narrow ductus and apically with ovoid and smooth bulla.

Egg description. The eggs were extracted from the dry abdomen and observed dry. Eggs are sub-elliptical (elongate-oval), yellowish, about $640 \mu \mathrm{m}$ long and about $300 \mu \mathrm{m}$ wide at mid-length (Figs 43-48 and 52$53)$. The egg surface has two main regions: a special- ised area on the antero-dorsal part and an unspecialised egg capsule.

The specialised area is characterised by a micropylar cap placed apically with sclerotised base with rounded spongy appearance. Surface of eggs with well developed polygonal cells with margins bearing nodules apically larger than in lower part of eggs; operculum absent. About 19 eggs were found in abdomen.

Distribution. Solomon Island: Western Province, New Georgia Island. 

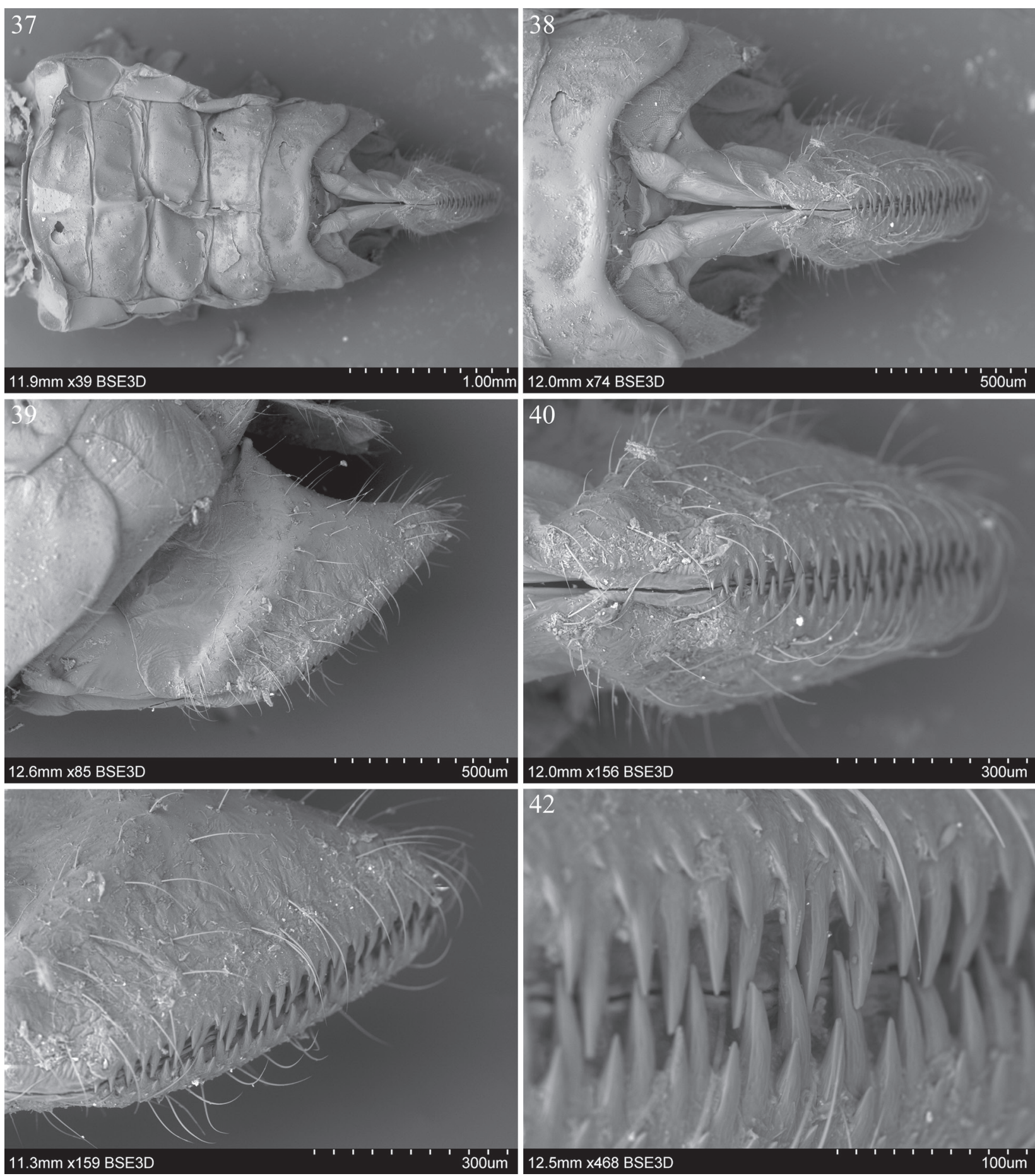

Figures 37-42. Kazukuru zingiberis gen. et sp. nov., SEM micrographs female terminalia; 37. Abdomen and terminalia, ventral view; 38. Pregenital sternite and terminalia, ventral view; 39. Gonoplac, lateral view; 40. Posterior margin of gonoplac, ventral view; 41. Same, ventro-lateral view; 42. Teeth of posterior margin of gonoplac.

\section{Kazukuru zingiberis sp. nov.}

http://zoobank.org/CD5F4BE6-B87C-469A-9A3F-0C8F9D59B92A

(Figs 1-60)

Etymology. The specific name zingiberis follows the host plant genus Zingiber Mill. on which the new species was collected. The specific name is intended as indeclinable.
Diagnosis. For now, a single species in the genus, see diagnosis of genus.

Description. Total length $0.85-0.86 \mathrm{~cm}$.

Head. Vertex: proportion $\mathrm{A} / \mathrm{B}=6.00$; anterior and posterior margins of vertex arcuate about same curvature; lateral margins almost straight and parallel.

Frons: proportion $\mathrm{C} / \mathrm{E}=1.15-1.20$; proportion $\mathrm{D} / \mathrm{E}=$ 1.73-1.80; upper margin weakly concave; frontoclypeal suture almost straight. 

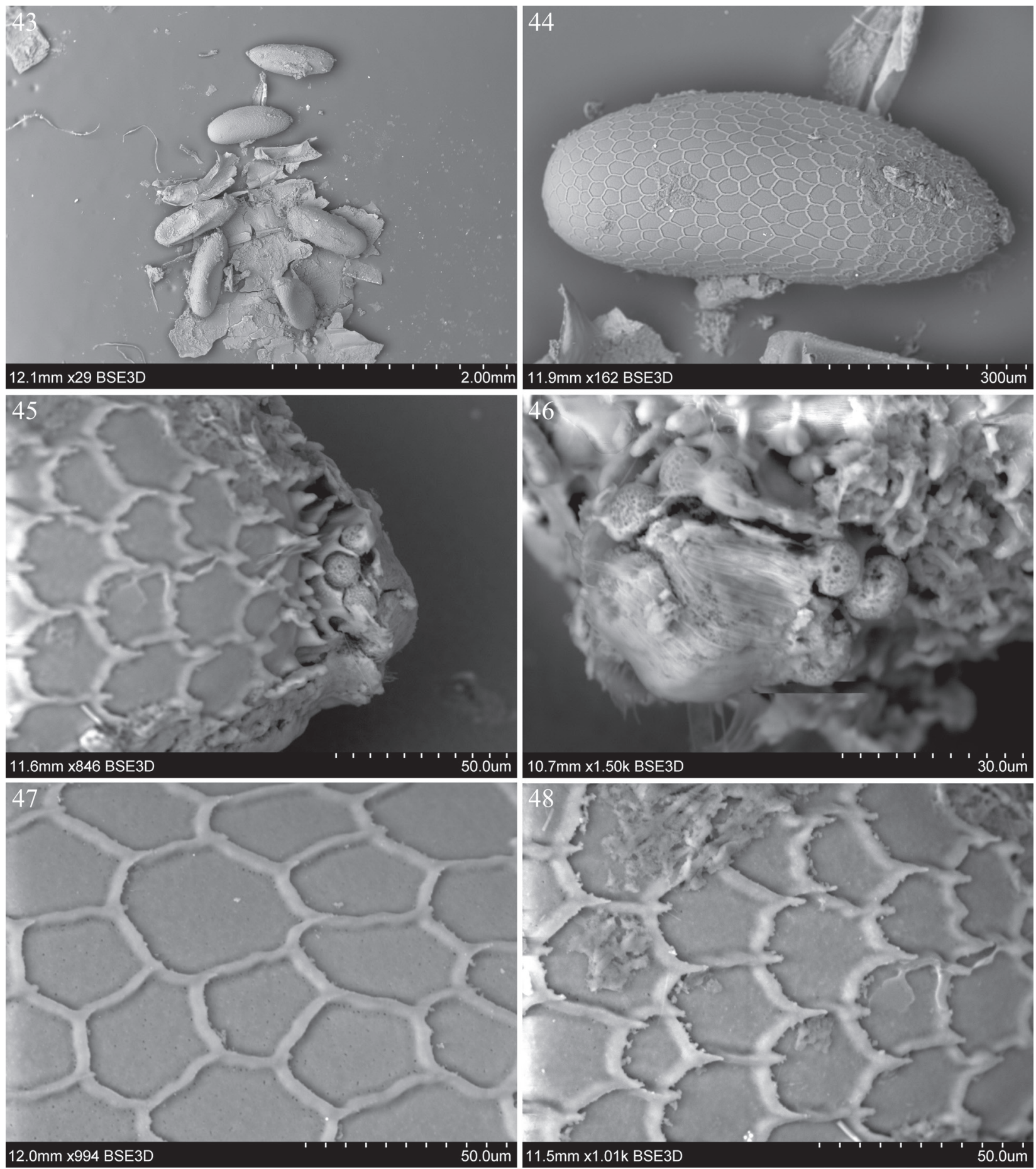

Figures 43-48. Eggs of Kazukuru zingiberis gen. et sp. nov., SEM micrographs; 43. Group of eggs; 44. Egg, lateral view; 45. Micropylar cap, lateral view; 46. Same, dorso-lateral view; 47. Polygonal cell, lower part of egg; 48. Same, dorsal part of egg.

Thorax. Pronotum: proportion $\mathrm{F} / \mathrm{B}=5.81-6.00$.

Mesonotum: proportion $\mathrm{G} / \mathrm{F}+\mathrm{B}=3.50-3.87$, proportion $\mathrm{G} / \mathrm{F}=5.81-6.00$, proportion $\mathrm{G} / \mathrm{H}=1.0$; connection between anterolateral carinae and lateral weakly visible.

Tegmina: proportion $\mathrm{I} / \mathrm{J}=1.71-1.77$; longitudinal veins $\mathrm{ScP}$ with single terminal; RA with single terminal; $\mathrm{MP}$ with 8 terminals $\left(\mathrm{MP}_{1+2}\right.$ with four terminals, $\mathrm{MP}_{3+4}$ with 4 terminals); RP with three terminals; $\mathrm{CuA}$ with three terminals. Hind wing. $\mathrm{ScP}+\mathrm{RA}$ not forking, single, $\mathrm{RP}$ single; $\mathrm{CuA}$ with three terminals.
Female terminalia. Anal tube (in dorsal view): posterior margin medially with distinct concavity.

Colouration (Figs 1-6 and 49-52). General colouration yellowish-brownish. Tegmina hyaline with a few brownish patches: elongate alongside $\mathrm{ScP}+\mathrm{R}$ vein; small rounded patch near posterior margin between $\mathrm{RP}$ forks and three separated, rounded patches present alongside $\mathrm{CuP}$ vein; tip of costal area yellowish. Abdomen (sternites and tergites) brownish with black patches (Figs 4952); terminalia brownish. 

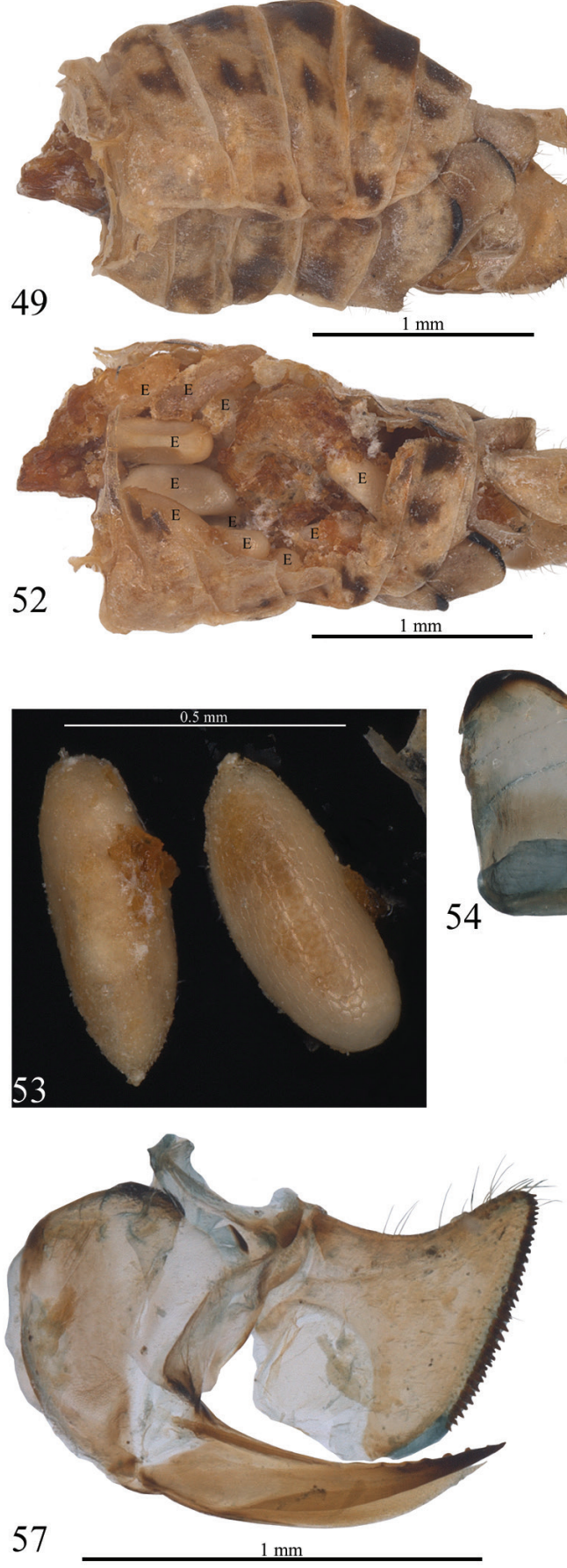
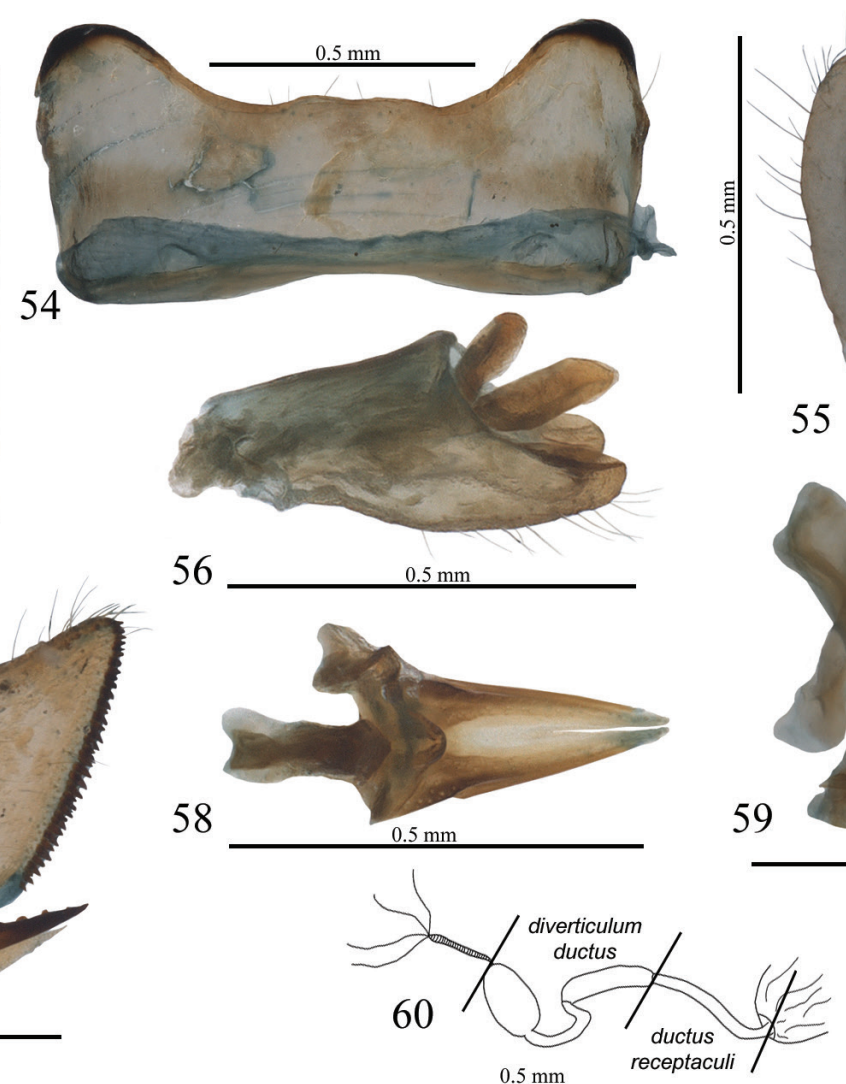

51

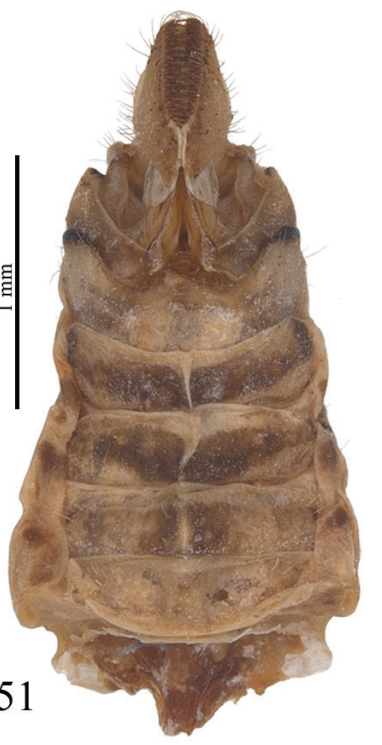

55
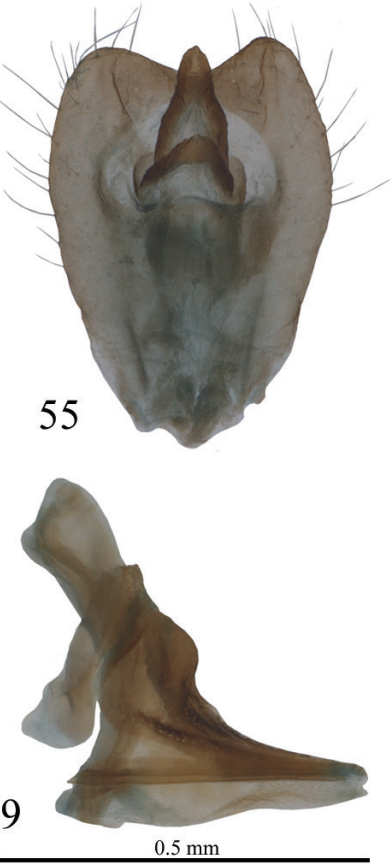

Figures 49-60. Kazukuru zingiberis gen. et sp. nov; 49. Abdomen and terminalia, lateral view; 50. Same, dorsal view; 51. Same, ventral view; 52. Abdomen with eggs; 53. Eggs; 54. Pregenital sternite, ventral view; 55. Anal tube, dorsal view; 56. Same, lateral view; 57. Gonoplac and gonapophysis VIII with endogonocoxal process, lateral view; 58. Gonaphophyses IX and gonospiculum bridge, dorsal view; 59. Same, lateral view; 60. Spermatheca.

Type material. Holotype, female: [Solomon Is.: / NEW Georgia Group / N. Georgia I., Munda / 1-30 m. VII-151959], [Ginger], [J. L. Gressitt / Collector] - BPBM.

Paratype, female: [Solomon Is.: / New Georgia Group / N. Georgia I., Munda / 1-30 m. VII-13-1959], [J. L. Gressitt / Collector] - BPBM.

Distribution. Solomon Island: Western Province, New Georgia Island.
Host plant. Genus Zingiber Mill. (as ginger; Order: Zingiberales Griseb., family: Zingiberaceae Martinov).

\section{Discussion}

The genus, described above, presents a set of unique characters that broadens our knowledge of the morphology 
diversity of planthoppers from the family Ricaniidae: the presence of a transverse shaft on the face and its double plane (upper part projected, lower part - below the shaft, retracted) and open cells $\mathrm{C}_{1}$ and $\mathrm{C}_{5}$ on the tegmen.

This unique set of characters within the family Ricaniidae allows the definitive description of this new species, based on only two female specimens, in a new genus, even in the absence of any male specimen. Its discovery in the future will be very interesting for completing the description with the male genitalia characteristics.

Knowledge about the host plants in relation with Ricaniidae is far from sufficient. The specimens of Kazukuru zingiberis gen. et sp. nov. were collected on ginger, Zingiber sp., a plant association not previously recorded for the family. The only other record from the family Zingiberaceae Martinov is Hedychium gardnerianum Sheppard ex Ker Gawl. (kahili ginger, wild ginger) for Scolypopa australis (Walker), a polyphagous species, recorded in New Zealand (Martin 2017).

The current knowledge about ricaniids egg ultrastructure is very scarce and high-resolution images from a scanning electron microscope (SEM) are only known for Ricania speculum (Walker, 1851) (Rossi et al. 2014). The present description is based on the eggs extracted from the dry abdomen, which share obvious similarities with eggs of $R$. speculum. Both eggs have the same shape, without operculum and have developed polygonal cells on the surface. Significant differences occur however in construction of micropylar caps. Unfortunately, these differences may be due to incomplete development of immature eggs. However, differences at the base of the cap (sclerotised in Kazukuru gen. nov., porous in Ricania) and spongious-like structures are observed in both species. A comparative morphology analysis of these characters would be of great interest in the future.

\section{Acknowledgements}

I would like to thank Prof. Thierry Bourgoin, Prof. Charles Bartlett and an anonymous Reviewer for their detailed and insightful comments on the manuscript.

\section{References}

Amyot CJ-B, Audinet-Serville JG (1843) Deuxième partie. Homoptères. Homoptera Latr. Histoire Naturelle des insectes. Hemiptères 1843: 1-676.

Bourgoin T (1988) A new interpretation of the homologies of the Hemiptera male genitalia, illustrated by the Tettigometridae (Hemiptera, Fulgoromorpha). In: Vidano C, Arzone A (Eds) $6^{\text {th }}$ Auchenorrhyncha Meeting, Turin, Italy, September 7-11, 1987. Consiglio Nazionale delle Ricerche-Special Project IPRA, Turin, 113-120.

Bourgoin T (1993) Female genitalia in Hemiptera Fulgoromorpha morphological and phylogenetic data. Annales de la Société entomologique de France 29(3): 225-244.
Bourgoin T (2021) FLOW (Fulgoromorpha Lists On the Web): a world knowledge base dedicated to Fulgoromorpha. Version 8, updated 202009-17. http:/hemiptera-databases.org/flow/ [Last access 2020-09-21]

Bourgoin T, Huang J (1990) Morphologie comparée des genitalia mâles des Trypetimorphini et remarques phylogénétiques (Hemiptera: Fulgoromorpha: Tropiduchidae). Annales de la Société entomologique de France, Nouvelle Série 26(4): 555-564.

Bourgoin T, Wang R-R, Asche M, Hoch H, Soulier-Perkins A, Stroiński A, Yap S, Szwedo J (2015) From micropterism to hyperpterism: recognition strategy and standardized homology-driven terminology of the forewing venation patterns in planthoppers (Hemiptera: Fulgoromorpha). Zoomorphology 134: 63-77. https://doi.org/10.1007/ s00435-014-0243-6

Bu C-P, Larivière MC, Liang A-P (2010) Parapiromis nom. nov., a new name for Piromis Fennah (Hemiptera: Fulgoromorpha: Ricaniidae), with descriptions of three new species. Zootaxa 2400: 29-40. https://doi.org/10.11646/zootaxa.2400.1.3

Carayon J (1969) Emploi du noir chlorazol en anatomie microscopique des insectes. Annales de la Société entomologique de France, Nouvelle Série 5: 179-193.

Distant WL (1911) Rhynchota from the Solomon Islands. Annals and Magazine of Natural History (Ser. 8)8: 384-388. https://doi. org $/ 10.1080 / 00222931108693047$

Donovan E (1805) An epitome of the natural history of the insects of New Holland, New Zealand, New Guinea, Otaheite, and other islands in the Indian, Southern, and Pacific Oceans. London, Not numbered. https://doi.org/10.5962/bhl.title.123219

Dunn M, Ross M (2007) Is Kazukuru really non-Austronesian? Oceanic Linguistics 46(1): 210-231. https://doi.org/10.1353/ol.2007.0018

Fennah RG (1970) Fulgoroidea (Homoptera) from Rennell \& Belona Islands. In: Wolff T (Ed.) The natural history of Rennell Islands, British Solomon Islands (Scientific Research of the Noona Dan Expedition (Rennell Section 1962) \& Danish Rennell Exp. 1965., 6. Danish Science Press, Copenhagen (Denmark), 43-85.

Guérin-Méneville FE (1838) Crustacées, arachnides et insectes. In: Duperrey LI (Ed.) Voyage autour du monde, exécuté par ordre du roi, sur la corvette de sa majesté, La Coquille, pendant les années 1822, 1823, 1824 et 1825, 2: 180-193.

Martin NA (2017) Passion vine hopper - Scolypopa australis. Interesting Insects and other Invertebrates. New Zealand Arthropod Factsheet Series Number 111. ISSN 1179-643X. http://nzacfactsheets. landcareresearch.co.nz/Index.html [(revised 2018) Date Accessed 28.01.2019]

Melichar L (1898) Vorläufige Beschreibnungen neuer Ricaniiden. Verhandlungen der Kaiserlich-Königlichen Zoologisch-botanischen Gesellschaft in Wien 48: 384-400.

Montrouzier X (1861) Essai sur la faune entomologique de la Nouvelle-Calédonie (Balade) et des iles des Pins, Art, Lifu, etc. Hémiptères. Annales de la Société Entomologique de France (Ser. 4)1: 59-74.

Rossi E, Stroiński A, Lucchi A (2015) Egg morphology, laying behavior and record of the host plants of Ricania speculum (Walker, 1851), a new alien species for Europe (Hemiptera: Ricaniidae). Zootaxa 4044(1): 093-104. https://doi.org/10.11646/zootaxa.4044.1.5

Stroiński A (2020) Redescription of the genus Lambertonia Lallemand, 1950 (Hemiptera: Fulgoromorpha: Ricaniidae) from Madagascar. Annales Zoologici 70(4): 653-666. https://doi.org/10.3161/000345 41ANZ2020.70.4.009 
Stroiński A, Gnezdilov VM, Bourgoin T (2011) Sub-brachypterous Ricaniidae (Hemiptera: Fulgoromorpha) of Madagascar with morphological notes for these taxa. Zootaxa 3145: 1-70. https://doi. org/10.11646/zootaxa.3145.1.1

Van Duzee EP (1940) New species of Hemiptera collected by the Templeton Crocker expedition to the Solomon Islands in 1933. Pan-Pacific Entomologist 16(4): 178-196.
Walker F (1851) List of the specimens of Homopterous insects in the collection of the British Museum 2: 261-636.

Walker F (1862) Characters of undescribed species of Homoptera in the collection of F. P. Pascoe, F. L. S. The Journal of Entomology: Descriptive and Geographical 1: 303-319. 